\title{
Spatial and temporal scales of patches of crab larvae in coastal waters
}

\author{
Cecily C. Natunewicz*, Charles E. Epifanio \\ University of Delaware, Graduate College of Marine Studies, 700 Pilottown Rd, Lewes, Delaware 19958, USA
}

\begin{abstract}
This study examined the spatial and temporal scales of patches of crab larvae in the coastal waters of the Middle Atlantic Bight near the mouth of Delaware Bay, USA $\left(38.70^{\circ} \mathrm{N}, 75^{\circ} \mathrm{W}\right)$. The spatial scale of the patches was characterized by sampling along-shelf and across-shelf transects via series of continuous plankton tows. Autocorrelation of larval densities along each transect revealed that patch diameters ranged from about 0.5 to $2.5 \mathrm{~km}$ in both along-shelf and across-shelf dimensions. The ages of 12 different patches were estimated by comparing the proportions of Stage I and Stage II larvae composing each patch. One additional patch was tagged with a satellitetracked drifter, and changes in the proportions of the 2 stages were observed over a $3 \mathrm{~d}$ period. Analysis indicated that the tagged patch had remained cohesive for at least $4 \mathrm{~d}$ and possibly as long as $6 \mathrm{~d}$. Potential mechanisms for patch formation and maintenance include synchronous spawning events, associative larval behavior, and aggregative physical processes.
\end{abstract}

KEY WORDS: Patch $\cdot$ Transport $\cdot$ Larvae $\cdot$ Callinectes sapidus $\cdot$ Delaware Bay

Resale or republication not permitted without written consent of the publisher

\section{INTRODUCTION}

Marine zooplankton are rarely distributed uniformly, but rather are found in discrete patches (e.g., Greene et al. 1994). Both physical and biological processes contribute to this heterogeneity. Physical processes that produce plankton patches on small spatial scales (10 to $10^{2} \mathrm{~m}$ ) include internal waves and Langmuir circulation (Franks 1997). Other factors such as tidal fronts and internal tidal bores are important in creating patches on medium scales $\left(10^{2}\right.$ to $\left.10^{4} \mathrm{~m}\right)$, while largescale patches $\left(>10^{4} \mathrm{~m}\right)$ have been attributed to features such as gyres, eddies and meanders (Pineda 1991, Thiébaut 1996). Biological processes also aid in the formation of patches. For example, factors such as vertical migration, synchronous spawning events, or interaction with prey organisms may be important in the formation of small- to medium-scale patches (Fortier \& Leggett 1984, Ouellet \& Lefaivre 1993, Ashjian et al. 1994).

*E-mail: cecilyn@udel.edu
Regardless of the mode of formation, patches do not remain stable through time, but instead undergo dispersion in response to physical processes (Thiébaut 1996). Experiments in the coastal ocean have shown that small-scale turbulence associated with horizontal current shear may reduce concentration gradients and homogenize patches of inanimate tracers on time scales of days to weeks (Franks 1997). Patches of zooplankton occurring in shelf waters are subject to similar mixing processes. Therefore, zooplankton patches in the coastal ocean are likely to disperse over time scales pertinent to horizontal transport.

While the physical and biological factors that control formation and dispersion of patches are reasonably well understood, there have been few actual measurements of patch dimensions in nature (Gallager et al. 1996). Moreover, there has been little success in following changes in these dimensions through time (Lee et al. 1992). This is particularly true for larval forms of marine fish and invertebrates, where an appreciation of patch dynamics is an essential component of the overall understanding of larval transport (Garvine et 
al. 1997). Measurement of patch size for larval forms has been limited to relatively few studies (e.g., Gallager et al. 1996, Thiébaut 1996), and efforts to track patches through time have been restricted primarily to ichthyoplankton (Fortier \& Leggett 1985, Stabeno et al. 1996).

The species of particular interest in our investigation was the blue crab Callinectes sapidus. In the Middle Atlantic region of North America, blue crab larvae are released in summer and are quickly exported from the mouths of estuaries to the coastal ocean. Over a period of 3 to $6 \mathrm{wk}$, the larvae develop through 7 zoeal stages in surface waters of the inner continental shelf. This is followed by a single postlarval stage of 1 to 2 wk duration that eventually settles and undergoes metamorphosis in nursery habitat within the estuary (Epifanio 1995 and references therein).

Details of blue crab larval transport in the Middle Atlantic region have been described in recent conceptual and mathematical models (Epifanio 1995, Garvine et al. 1997). These models stipulate initial transport of zoeae southward along the inner continental shelf within the buoyant estuarine plume. Transport back toward the estuary is provided by a wind-driven band of water flowing northward along the mid-shelf. Across-shelf transport to estuarine settlement sites is accomplished by coastal Ekman circulation associated with discrete southward wind events.

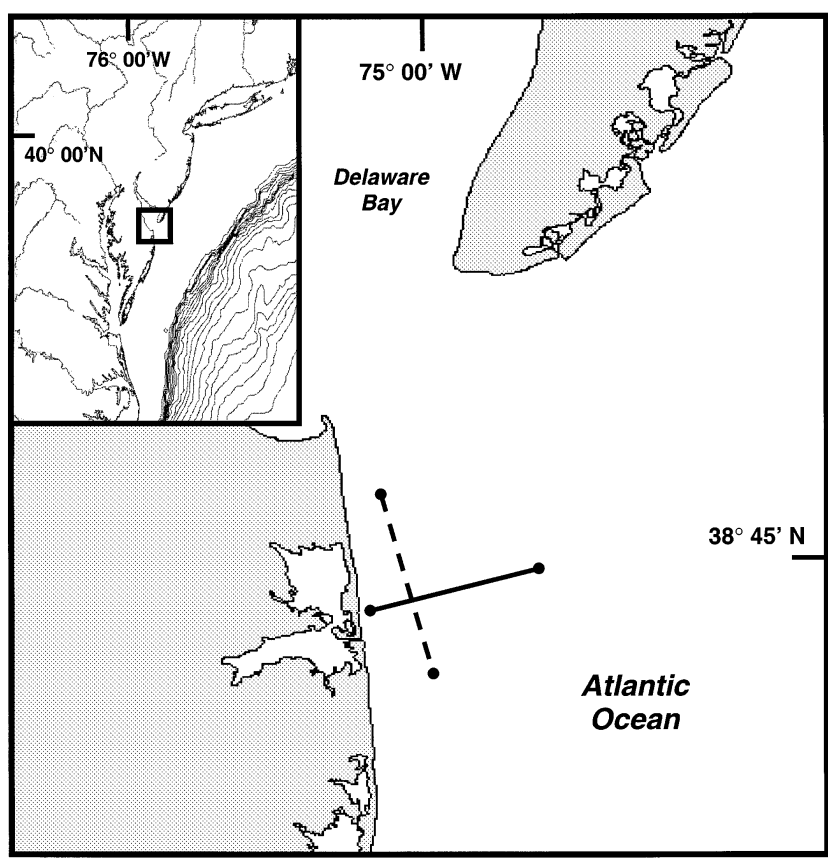

Fig. 1. Map of sampling area. Representative along-shelf (dashed line) and across-shelf (solid line) transects sampled in the summer of 1998. Inset: Middle Atlantic Bight, USA
Although transport of blue crab larvae is described well by the models outlined above, the distribution $\left(10^{2}\right.$ to $\left.10^{4} \mathrm{~m}\right)$ of larvae on the continental shelf remains unknown. Field observations and model experiments indicate that settlement of postlarvae in estuarine habitats occurs as discrete pulses in time that follow some, yet not all, southward wind events (Jones \& Epifanio 1995, Garvine et al. 1997). This suggests that the distribution of post-larvae and larvae in coastal waters is patchy in nature. However, the existence of temporal pulses in settlement provides only circumstantial evidence for the assumption of patchiness in space, and patches of crab larvae have never been documented in the field.

In this paper we describe results of a field investigation that was designed to determine the length scales of patches of blue crab larvae along and across the continental shelf adjacent to Delaware Bay, USA. In addition, we estimated time scales (duration) of patches by determining the most prevalent larval stages found in the patches and calculating the maximum period of patch cohesiveness assuming a 3 to 6 d duration for each stage. We examined temporal changes in proportions of different larval stages by tagging one patch with a satellite-tracked Lagrangian drifter and following the patch for $3 \mathrm{~d}$.

\section{MATERIALS AND METHODS}

Study area. Our study was conducted in the southern Middle Atlantic Bight at the mouth of Delaware Bay (Fig. 1). Subtidal flow in this area is influenced by a buoyant plume emanating from the bay. The plume flows southward along the coast and counter to the prevailing northward winds that are typical of summer in the region. These winds result in an upwelling circulation along the coast and also produce northward surface flow just offshore of the plume (Garvine et al. 1997). Early autumn is characterized by an increased frequency of southward wind events. These events drive downwelling circulation that causes an increase in sea level along the coast, followed by barotropic flow into the bay (Münchow \& Garvine 1993).

Spatial scale. Sampling was conducted from July to September 1998, during the spawning season of Callinectes sapidus. The spatial scale of larval patches was determined via series of plankton tows $(0.5 \mathrm{~m}$ diameter nets, $253 \mu \mathrm{m}$ mesh) performed from an $8 \mathrm{~m}$ boat. The volume of water filtered through the nets was derived from flowmeters (General Oceanics Model 2030) secured in the center of the net. Distance towed was determined with differential GPS (global positioning system). Sampling was always conducted in a $2 \mathrm{~h}$ period around high slack water. Thus, towing speed 
was always much greater than the speed of tidal currents, and there was little displacement of water in relation to the sampling transects. Wind speed on sampling days was also generally low $\left(<5 \mathrm{~m} \mathrm{~s}^{-1}\right)$, and therefore wind-driven surface currents were unlikely to affect the volume of water sampled with each tow.

Tows were taken along transects in both along-shelf and across-shelf directions (Fig. 1). Along-shelf transects were positioned parallel to the main channel of Delaware Bay. Across-shelf transects were perpendicular to the channel and always intersected the along-shelf transect. Because Callinectes sapidus larvae remain in the upper $2 \mathrm{~m}$ of the water column throughout development (Epifanio 1995 and references therein), surface tows were sufficient to determine spatial scales of the patches.

We conducted 2 types of sampling (continuous and interval) over the course of the study (Table 1). Individual tows were always $300 \mathrm{~m}$ in length and filtered about $35 \mathrm{~m}^{3}$ of water. At the beginning of each tow, temperature and salinity were measured with a salinity-conductivity-temperature meter. Continuous sampling consisted of a series of tows wherein retrieval of one net always coincided with deployment of another. This method allowed a continuous record of larval density, but placed practical limitations on the length of each transect (maximum $=7.2 \mathrm{~km}$ ). In contrast, interval sampling involved a series of $300 \mathrm{~m}$ tows taken at $800 \mathrm{~m}$ intervals. This allowed us to sample over a longer transect (maximum $=18.7 \mathrm{~km}$ ), but required linear interpolation of larval densities across intervals. Overall, we sampled on 10 separate days. These consisted of 3 days during which we sampled in the alongshelf direction, 1 day on which we sampled in the across-shelf direction, 4 days during which we sampled in both along-shelf and across-shelf directions, and 2 days during which we sampled a tagged patch (see below).

Table 1. Callinectes sapidus. Dimensions of patches (m) of zoea larvae near the mouth of Delaware Bay, USA. Sampling method (continuous or interval) is described in the text. (-) Dimension was not sampled

\begin{tabular}{|lccc|}
\hline $\begin{array}{l}\text { Date } \\
(1998)\end{array}$ & Method & $\begin{array}{c}\text { Along-shelf } \\
\text { dimension (m) }\end{array}$ & $\begin{array}{c}\text { Across-shelf } \\
\text { dimension (m) }\end{array}$ \\
\hline $13 \mathrm{Jul}$ & Continuous & 2000 & - \\
$15 \mathrm{Jul}$ & Continuous & 500 & - \\
$22 \mathrm{Jul}$ & Continuous & - & 1000 \\
$24 \mathrm{Jul}$ & Continuous & 1400 & - \\
$10 \mathrm{Aug}$ & Continuous & 2400 & - \\
$20 \mathrm{Aug}$ & Continuous & 1200 & 2200 \\
$21 \mathrm{Aug}$ & Continuous & 2200 & 1600 \\
$2 \mathrm{Sep}$ & Interval & 2000 & 2200 \\
$3 \mathrm{Sep}$ & Interval & 1600 & 1200 \\
\hline
\end{tabular}

Samples were preserved and analyzed using standard techniques (Dittel \& Epifanio 1982). Each sample was split 4 to 6 times using a Folsom plankton splitter, and 1 of the 16 to 64 resulting subsamples was selected randomly for analysis. Blue crab zoeae were separated from the rest of the plankton, staged, and counted (Sandifer 1972).

Temporal scale. Because transects were located near the blue crab spawning grounds in lower Delaware Bay, samples were always dominated by early-stage larvae. The age of a given patch was estimated by comparing the proportions of Stage I and Stage II zoeae in the samples. This approach was based on previous reports indicating that duration of each stage varies among individual larvae, but generally falls in the range of 3 to $6 \mathrm{~d}$ (Sulkin 1975, Epifanio 1995). Thus, a patch containing only Stage I larvae could have been as young as $1 \mathrm{~d}$ and as old as $6 \mathrm{~d}$. Accordingly, patches containing high numbers of both Stage I and Stage II larvae were estimated to be 4 to $6 \mathrm{~d}$ old.

On one occasion (10 to 13 August) we were able to examine temporal changes in the proportion of larval stages in a patch, by deploying 4 satellite-tracked drifters (Horizon Marine, FHD/Holey Sock) while sampling an along-shelf transect. This was done by releasing a drifter during every 6th plankton tow, i.e., every $1800 \mathrm{~m}$ along the $7200 \mathrm{~m}$ transect. Samples from the drifter sites were analyzed immediately in the laboratory, where it was determined that 1 of the drifters had been deployed in a patch of Stage I larvae (density > $100 \mathrm{~m}^{-3}$ ). This drifter was tracked by the Argos, a satellite system used for global data collection, and re-located with an automated radio-direction finder. Because of inclement weather, the area around the drifter was not sampled again until 13 August. By this time the patch had been transported approximately $25 \mathrm{~km}$ southward from its initial location. The second sampling was conducted along 2 orthogonal transects that crossed at the drifter. Each transect consisted of 6 contiguous $300 \mathrm{~m}$ tows centered on the drifter (Table 1). A 3rd sampling on 15 August determined that the drifter was no longer in the patch.

Statistical analysis of patch dimensions. We used autocorrelation analysis to determine patch dimensions in both the along-shelf and across-shelf directions (Chatfield 1984). In our analysis, observations of larval densities were correlated at successive lags (i.e., the distance between samples) of $300 \mathrm{~m}$ (continuous samples) or $800 \mathrm{~m}$ (interval samples). Autocorrelation coefficients were calculated for a total of 10 lags transect ${ }^{-1}$.

We considered the point in space at which the larval densities first became decorrelated as the characteristic length scale of a patch (Rowe \& Epifanio 1994). Decorrelation occurs when the value of the autocorrelation coefficient is not different from zero (Richerson 
et al. 1977). In practice this is the point at which the value of the coefficient falls below the value of Bartlett's Standard Error (Box \& Jenkins 1976). Bartlett's Standard Error is an estimate of the standard error of the autocorrelation function at each point in its

Table 2. Callinectes sapidus. Correlations of the respective abundances of Stage I and Stage II zoea larvae along transects spanning each patch. (-) No Stage II zoeae occurred within a patch. ${ }^{*} \mathrm{p}<0.05,{ }^{* *} \mathrm{p}<0.01$

\begin{tabular}{|llc|}
\hline Date (1998) & Dimension & Correlation coefficient \\
\hline 13 Jul & Along-shelf & 0.182 \\
15 Jul & Along-shelf & $0.737^{* *}$ \\
$22 \mathrm{Jul}$ & Across-shelf & - \\
$24 \mathrm{Jul}$ & Along-shelf & $0.427^{*}$ \\
$10 \mathrm{Aug}$ & Along-shelf & $0.801^{* *}$ \\
$13 \mathrm{Aug}$ & Along-shelf & $0.943^{* *}$ \\
$13 \mathrm{Aug}$ & Across-shelf & $0.988^{* *}$ \\
$20 \mathrm{Aug}$ & Along-shelf & $0.821^{* *}$ \\
$20 \mathrm{Aug}$ & Across-shelf & $0.700^{* *}$ \\
$21 \mathrm{Aug}$ & Along-shelf & $0.469^{*}$ \\
$21 \mathrm{Aug}$ & Across-shelf & 0.328 \\
$2 \mathrm{Sep}$ & Along-shelf & $0.422^{*}$ \\
$2 \mathrm{Sep}$ & Across-shelf & $0.926^{* *}$ \\
3 Sep & Along-shelf & $0.847^{* *}$ \\
$3 \mathrm{Sep}$ & Across-shelf & $0.809^{* *}$ \\
\hline
\end{tabular}
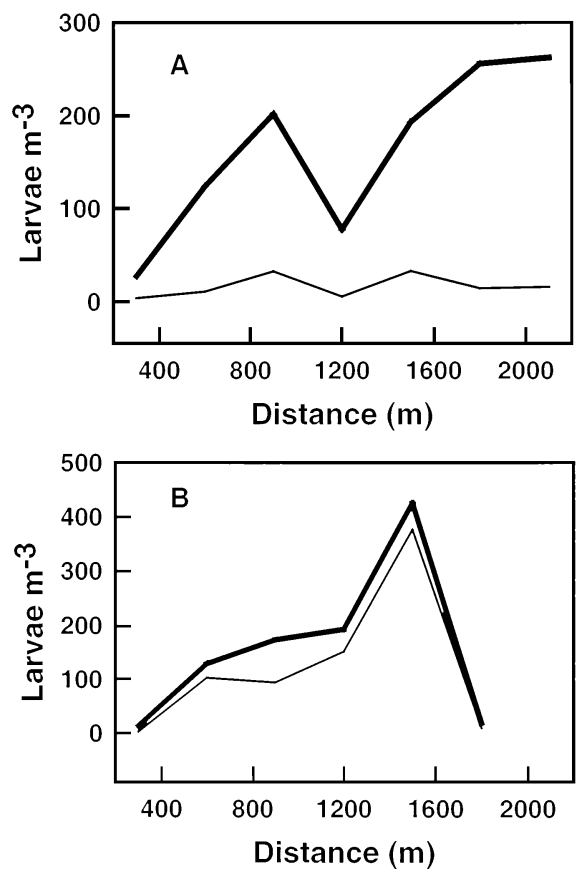

Fig. 2. Callinectes sapidus. Densities of Stage I (bold line) and Stage II (thin line) zoeae along a transect within a tagged patch. (A) 10 August 1998. Densities of the 2 stages are significantly correlated in space $(\mathrm{R}=0.80, \mathrm{p}<0.01)$, but note the small percentage of Stage II. (B) 13 August 1998. Densities of the 2 stages are significantly correlated in space $(R=0.94, p<$ 0.01 ), but note the relatively high percentage of Stage II domain. The characteristic length scale of a patch is half its linear dimension (Richerson et al. 1977). Hereafter, we characterize each patch by its entire alongshelf or across-shelf dimension, or twice the characteristic length scale.

We also ran simple correlations to determine the relationship between densities of Stage I and Stage II zoea larvae at the various sampling sites within a patch. Specifically, the spatial series of Stage I densities was correlated with the series of Stage II densities. We used the results of this analysis to support our estimates of patch age. For example, when there was a significant correlation between densities of Stage I and Stage II larvae within a patch (i.e., the relative proportions of the 2 stages remained constant within a patch), it was reasonable to conclude that all of the larvae were from the same spawning cohort, but that some individuals had already undergone a molt to the second stage. Because the duration of the 2 stages was known, it was then possible estimate the age of the patch (see above.)

\section{RESULTS}

Physical data suggested that patches of larvae were located mainly within the estuarine plume. The latter was indicated by warm surface temperatures and low salinities $\left(\sim 25^{\circ} \mathrm{C}, 30 \%\right)$ that contrasted with the lower temperatures and higher salinities $\left(\sim 24^{\circ} \mathrm{C}, \sim 31 \%\right.$ o $)$ in adjacent shelf waters.

Results of autocorrelation analysis showed that dimensions of individual patches ranged from 500 to $2400 \mathrm{~m}$ in the along-shelf direction and 1000 to $2200 \mathrm{~m}$ in the across-shelf direction (Table 1).

There was a significant correlation between the densities of Stage I and Stage II zoeae in 12 of the 14 transects sampled, indicating that these patches had remained cohesive for 4 to $6 \mathrm{~d}$ (Table 2). The correlation between densities of sequential zoeal stages in the tagged patch provided additional evidence that patches remain cohesive through time (Fig. 2). On 10 August, the patch was dominated by Stage I larvae, with maximum density of $\sim 300 \mathrm{~m}^{-3}$. On 13 August the composition of the patch was split more evenly between Stage I and Stage II larvae. Moreover, there was a highly significant correlation $(\mathrm{R}=0.988)$ between the densities of the 2 stages at the various sampling sites within the patch. This suggested that many of the Stage I zoeae in the initial sampling had since molted to Stage II and indicated that the age of the patch was between 4 and $6 \mathrm{~d}$. Differences in overall abundance of larvae were probably due to the fact that we did not sample the exact same location in the patch on each of the sampling dates. 


\section{DISCUSSION}

The results of our study show that early-stage blue crab larvae are distributed in discrete patches and that these patches are cohesive on a time scale of days to a week. The diameters of the patches ranged from 0.5 to $2.4 \mathrm{~km}$. Because all samples in our investigation were dominated by Stage I zoeae, it is likely that patches were generated near the time of spawning. Patches of larval fish have been associated with large aggregations of spawning adults (Fortier \& Leggett 1984), and this may be the mechanism that produced patches of crab larvae in our investigation (Provenzano et al. 1983). If the newly hatched larvae were released by aggregations of females within an area circumscribed by hundreds of meters to a few kilometers, they would have formed patches on the scales observed in this study. Patch diameters on the order of $10^{3}$ to $10^{4} \mathrm{~m}$ also correspond to the width of the main channel at the mouth of Delaware Bay, a feature that could concentrate newly released zoea larvae.

The length scales of the individual larval patches found in this study were nevertheless quite varied. Roman \& Boicourt (1999) showed that upwelling-favorable (northward) winds spread the estuarine plume offshore, while downwelling-favorable winds condensed the plume. These processes may have affected the size of patches in our study; however, our data were insufficient to allow quantitative analysis of their effects.

The temporal scales determined in our study support existing models that postulate wind-driven transport of Callinectes sapidus larvae in the coastal ocean (Epifanio 1995, Garvine et al. 1997). Our results show that some patches remained cohesive for periods of at least $6 \mathrm{~d}$, which constitutes nearly $30 \%$ of the entire period of zoeal development. This lends credence to the idea that the observed pattern of settlement in this species may result from across-shelf transport of discrete patches of postlarvae that have remained cohesive since spawning (Jones \& Epifanio 1995).

There are a number of physical processes that promote the formation of patches in the coastal ocean. However, the spatial and temporal scales ( $\mathrm{km}$, days to weeks) of patches in this study more closely match the scales of dispersive processes (e.g., horizontal and vertical current shear and horizontal turbulence) This indicates that patches of larvae should disperse with time and implies that aggregative physical processes are insufficient to maintain patch integrity. Because blue crab larvae maintain a surface distribution throughout development, we can also discount diel vertical migration as a possible mechanism for maintenance of patches. However, horizontal swimming that results in swarming of the larvae is a possibility.
Associative behavior that assists in maintenance of patches is a common subject in the literature dealing with fish larvae (e.g., Davis \& Olla 1995, Stabeno et al. 1996), but has received little attention among invertebrate species. Indeed, the literature dealing with transport of crustacean larvae is almost entirely devoted to swimming in the vertical plane (Sulkin et al. 1980, Tankersley \& Forward 1994). Only the work of Harvey \& Epifanio (1997) suggests horizontal swimming in response to pressure waves generated by co-occurring zooplankton, but that investigation did not include any direct measurements of larval behavior, and the implication of horizontal swimming is based solely on inference drawn from prey-selection experiments.

Regardless of uncertainties concerning the maintenance of patches, our study has provided clear evidence concerning their spatial scale in the coastal ocean. Our data indicate that patches form at the time of hatching and remain cohesive through the first 2 zoeal stages, in spite of a generally dispersive physical environment. Evidence from earlier studies suggests that the postlarval form of Callinectes sapidus is also distributed in discrete aggregations (Jones \& Epifanio 1995, van Montfrans et al. 1995). It is unclear whether the intervening zoeal stages are distributed in patches or whether some physical process (e.g., Beardsley et al. 1996, Epstein \& Beardsley 2001) results in aggregation of postlarvae as they return to the estuary.

Acknowledgements. We would like to thank R. W. Garvine for his helpful suggestions as well as his comments on the manuscript. Field assistance was provided by W. R. Andrews, C. Di Meo, M. B. Jones, C. McKinney-Richards, G. Perovich, D. Ruppel, S. Schwalm, and K. Traexler. Computer assistance was provided by C. Janzen, T. Sanders, M. Whitney and R. Zagar. This project was supported by funds from the University of Delaware Sea Grant College Program and from the National Science Foundation (GER-9453990).

\section{LITERATURE CITED}

Ashjian CJ, Smith SL, Flagg CN, Mariano AJ, Behrens WJ, Lane PV (1994) The influence of a Gulf Stream meander on the distribution of zooplankton biomass in the slope water, the Gulf Stream, and the Sargasso Sea, described using a shipboard acoustic Doppler current profiler. DeepSea Res 41:23-50

Beardsley RC, Epstein AW, Chen C, Wishner KF, Macaulay MC, Kenney RD (1996) Spatial variability in zooplankton abundance near feeding right whales in the Great South Channel. Deep-Sea Res II 43:1601-1625

Box GE, Jenkins GM (1976) Time series analysis; forecasting and control. Holden-Day, New York, p 23-38

Chatfield C (1984) The analysis of time series, an introduction, 3rd edn. Chapman and Hall, San Francisco, CA

Davis MW, Olla BL (1995) Formation and maintenance of aggregations of walleye pollock Theragra chaleogramma larvae under laboratory conditions: the role of visual and chemical stimuli. Environ Biol Fishes 44:385-392 
Dittel AI, Epifanio CE (1982) Seasonal abundance and vertical distribution of crab larvae in Delaware Bay. Estuaries 5:197-202

Epifanio CE (1995) Transport of blue crab (Callinectes sapidus) larvae in the waters off mid-Atlantic states. Bull Mar Sci 57:713-725

Epstein AW, Beardsley RC (2001) Flow-induced aggregation of plankton at a front: a 2-D Eulerian model study. DeepSea Res II 48:395-418

Fortier L, Leggett W (1984) Small-scale covariability in the abundance of fish larvae and their prey. Can J Fish Aquat Sci 41:502-512

Fortier L, Leggett W (1985) A drift study of larval fish survival. Mar Ecol Prog Ser 25:245-257

Franks PJS (1997) Spatial patterns in dense algal blooms. Limnol Oceanogr 42:1297-1305

Gallager SM, Davis CS, Epstein AW, Solow A, Beardsley RC (1996) High-resolution observations of plankton spatial distributions correlated with hydrography in the Great South Channel, Georges Bank. Deep Sea Res II 43: 1627-1663

Garvine RW, Epifanio CE, Epifanio CC, Wong KC (1997) Transport and recruitment of blue crab larvae: a model with advection and mortality. Estuar Coast Shelf Sci 45: 99-111

Greene CH, Wiebe PH, Zaman JE (1994) Acoustic visualization of patch dynamics in oceanic ecosystems. Oceanography 7:4-12

Harvey E, Epifanio CE (1997) Prey selection by larvae of the common mud crab Panopeus herbstii Milne-Edwards. J Exp Mar Biol Ecol 217:79-91

Jones MB, Epifanio CE (1995) Settlement of brachyuran megalopae in Delaware Bay: an analysis of time series data. Mar Ecol Prog Ser 125:67-76

Lee TN, Rooth C, Williams E, McGowan M, Szmant AF, Clarke ME (1992) Influence of Florida Current, gyres, and wind-driven circulation on transport of larvae and recruitment in the Florida Keys coral reefs. Cont Shelf Res 12: 971-1002

Münchow A, Garvine RW (1993) Buoyancy and wind forcing of a coastal current. J Mar Res 51:298-322

Oullet P, Lefaivre D (1994) Vertical distribution of northern shrimp (Pandalus borealis) larvae in the Gulf of St. Lawrence; implications for trophic interactions and transport. Can J Fish Aquat Sci 51:123-132

Editorial responsibility: Otto Kinne (Editor), Oldendorf/Luhe, Germany
Pineda J (1991) Predictable upwelling and the shoreward transport of planktonic larvae by internal tidal bores. Science 253:548-551

Provenzano AJ Jr, McConaugha JR, Philips KB, Johnson DF, Clark J (1983) Vertical distribution of first stage larvae of the blue crab, Callinectes sapidus, at the mouth of Chesapeake Bay. Estuar Coast Shelf Sci 16:489-499

Richerson PJ, Powell TM, Leigh-Abbott MR, Coil JA (1977) Spatial heterogeneity in closed basins. In: Steele J (ed) Spatial patterns in plankton communities. Plenum Press, New York, p 239-276

Roman MR, Boicourt WC (1999) Dispersion and recruitment of crab larvae in the Chesapeake Bay plume: physical and biological controls. Estuaries 22:563-574

Rowe PM, Epifanio CE (1994) Tidal stream transport of weakifish larvae in Delaware bay, USA. Mar Ecol Prog Ser 110: 105-114

Sandifer PA (1972) Morphology and ecology of Chesapeake Bay decapod crustacean larvae. PhD thesis, Univ of Virginia, Charlottesville, VA

Stabeno PJ, Schumacher JD, Bailey KM, Brodeur RD, Cokelet ED (1996) Observed patches of walleye pollock eggs and larvae in Shelikof Strait, Alaska: their characteristics, formation and persistence. Fish Oceanogr 5:81-91

Sulkin SD (1975) The significance of diet in the growth and development of larvae of the blue crab, Callinectes sapidus Rathbun, under laboratory conditions. J Exp Mar Biol Ecol 20:119-135

Sulkin SD, van Heukelem W, Kelly P, van Heukelem L (1980) The behavioral basis of larval recruitment in the crab Callinectes sapidus Rathbun: a laboratory investigation of ontogenetic changes in geotaxis and barokinesis. Biol Bull 159:402-417

Tankersley RA, Forward RB Jr (1994) Endogenous swimming rhythms in estuarine crab megalopae: implications for flood-tide transport. Mar Biol 118:415-243

Thiébaut E (1996) Distribution of Pectinaria koreni larvae (Annelida: Polychaeta) in relation to the Seine River plume front (eastern English Channel). Estuar Coast Shelf Sci 43:383-397

van Montfrans J, Epifanio CE, Knott DM, Lipcius RN, Mense DJ, Metcalf KS, Olmi EJ III, Orth RJ, Posey $\mathrm{MH}$, Wenner EL, West TL (1995) Settlement of blue crab postlarvae in western North Atlantic estuaries. Bull Mar Sci 57:834-854

Submitted: March 9, 2000; Accepted: December 7, 2000

Proofs received from author(s): February 23, 2001 